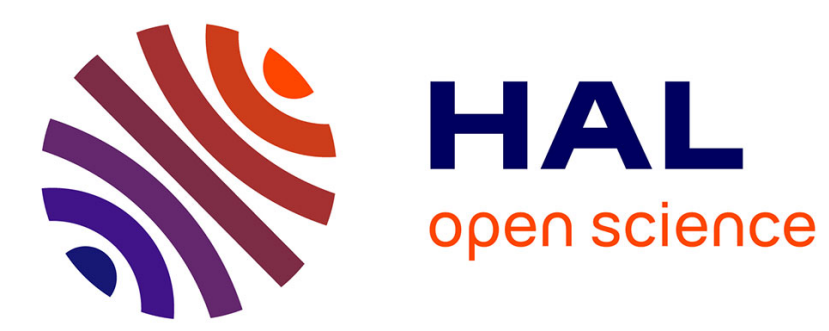

\title{
Impacts of Proximity Deliveries on e-Grocery Trips
}

Bruno Durand, Jesus Gonzalez-Feliu

\section{- To cite this version:}

Bruno Durand, Jesus Gonzalez-Feliu. Impacts of Proximity Deliveries on e-Grocery Trips. Supply

Chain Forum: An International Journal, 2012, pp.10-19. halshs-00795425

\section{HAL Id: halshs-00795425 \\ https://shs.hal.science/halshs-00795425}

Submitted on 28 Feb 2013

HAL is a multi-disciplinary open access archive for the deposit and dissemination of scientific research documents, whether they are published or not. The documents may come from teaching and research institutions in France or abroad, or from public or private research centers.
L'archive ouverte pluridisciplinaire HAL, est destinée au dépôt et à la diffusion de documents scientifiques de niveau recherche, publiés ou non, émanant des établissements d'enseignement et de recherche français ou étrangers, des laboratoires publics ou privés. 


\title{
Impacts of Proximity Deliveries on e-Grocery Trips
}

\author{
Bruno Durand \\ University of Nantes (Lemna), France \\ (bruno.durand@univ-nantes.fr) \\ Jesus Gonzalez-Féliu \\ University of Lyon 2 (Let), France \\ (jesus.gonzales-feliu@let.ish-lyon.cnrs.fr)
}

Bruno Durand is a Lecturer in Management Sciences at the University of Nantes, where he co-manages the International Logistic fifth year university program in the Language Faculty (Department of Applied Foreign Languages). ASLOG administrator (French Logistics' Association), he pursues his research work within the LEMNA (Nantes-Atlantic Laboratory of Economy and Management), more particularly in the field of e-logistics and in that of city logistics.

Jesus Gonzalez-Feliu is a Research Engineer at the French National Centre of Scientific Research (CNRS), and member of the Laboratory of Economy in Transportation (LET). He passed his Ph.D. in information and systems engineering in 2008 at Politecnico di Torino (Turin, Italy) in the subject of operations research applied to urban freight distribution solutions and two-echelon vehicle routing problems. His research interests include city logistics planning and policy, decision support systems, shopping trip modeling and the effects of e-commerce on urban mobility, transportation system optimization and performance and collaborative transportation.

\begin{abstract}
This paper proposes a discussion of three scenarios related to French e-grocery developments, in order to identify and analyze the impacts of new forms of proximity deliveries on households' shopping trip flows. One of our objectives will be to consider logistics solutions adopted by online retailers. Firstly, we present the two basic models of B2C: order-picking on a dedicated site and in-store picking. Secondly, we evaluate three distribution systems adopted by French e-grocery retailers. We focus in particular on the impact of these systems on consumers' purchasing trips and, to this end, we will use an empirical simulation approach to make a comparison of the systems studied.
\end{abstract}

Keywords: e-Grocery, Warehouse-picking, Store-picking, Home Delivery (HD), Out of Home Delivery (OHD) 


\section{INTRODUCTION}

After a slow start, particularly in France, the BtoC (Business to Consumer) services is now booming sometimes leading to fractures, especially in logistics (order-picking and deliveries). It therefore seems urgent to be concerned with deliveries to Internet users, either directly at home or to pick-up points, because city logistics could become a key factor in online selling development success or failure. In the past decades, city logistics has been developed to deal with the main problems of urban freight distribution, studying freight movements in urban areas and proposing solutions to reduce congestion and pollution. Moreover, end-consumer movements, related to household supply, have recently been studied from a city logistics point of view (Gonzalez-Feliu et al., 2012). However, most of these studies take into account only traditional shopping trips, avoiding several categories of trips related to e-commerce and teleshopping distribution channels. Moreover, e-commerce related studies focus on customer choices or optimization approaches in fields like culture and clothing (Taniguchi \& Kakimoto, 2003; Rohm \& Swaminathan, 2004), whilst e-grocery, one of the fields with stronger potentials, is less studied (Durand \& Vlad, 2011).

For this reason we decided to focus on e-grocery. We wish, in particular, to focus on interactions between e-grocery end-consumer flows and city logistics systems. Thus, one of our objectives will be firstly to consider logistics solutions adopted by online retailers. We present the two basic models of e-grocery distribution: order-picking on a site dedicated to this preparation and in-store picking. Secondly, we evaluate the three distribution systems adopted by the French e-grocery retailers. We focus in particular on the impact of these systems on consumers purchasing journeys and, to this end, we propose a simulation approach empirically built from data surveyed to make a comparison of the systems studied.

\section{E-SUPPLY CHAIN MANAGEMENT}

Logistics plays a major role in e-commerce success, yet its status remains secondary. Indeed, when an on-line shopper receives its order under the expected conditions, there is no reason to linger there. However, when logistics leaves something to be desired (delay, theft, loss, etc), it could be crippling for the continuation of purchases on the website frequented. Logistics 
performance is therefore, an obvious element of on-line sales; it is an integral part of transaction.

At the same time, as underlined by Baglin et al. (2005), B2C imposes specific logistics that, in particular, depend on the products sold. There are almost as many e-logistics as families of products and the choice of one of them by the cyber-storekeeper, if it is guided of course by the nature of products, also depends on the nature of the retailer: a storekeeper, only present online will not choose the same options as a colleague who also sells in-store. Essays concerning typologies are regularly the object of academic research in this area, in particular concerning model choice criteria (Durand, 2008).

According to Dornier \& Fender (2001), logistics is an essential component of web-based retailers' strategies, also defined as e-tailers. More precisely, two main components can be identified in strategic logistics management for e-commerce activities: inventory strategies and transport schemes. If we observe online order-picking (related to inventory), we can define two basic organizational models (Paché, 2008): (1) order-picking at a dedicated site; for example, an upstream national or regional warehouse (warehouse-picking) or closer to the place of consumption in a downstream local depot (depot-picking); (2) store-picking.

\subsection{Order-picking at a dedicated site}

According to De Koster (2002), when the number of SKU (Stock Keeping Units) for B2C is large (several tens of thousands) and when the on-line activity is not marginal (several hundreds of orders a day), storage on a specific site, dedicated to e-commerce, seems a necessity. Three alternative inventory schemas have been considered: (1) upstream storage, in producers' warehouses for slow moving items; (2) more downstream storage, for fast moving products, in national (or interregional) warehouses dedicated to e-commerce and managed by distributors and/or LSPs (Logistics Service Provider); (3) far downstream storage, for very fast moving articles in urban (or suburban) depots, directly connected to on-line sales structures and directly managed by distribution companies.

Let us specify that the first alternative, that of the order-picking in producers' warehouses, contains several variants (Durand, 2010). We will look at the variant that minimizes the number of HDs (Home Delivery) and examine its process (cf. Figure 1). First, on-line consumers place orders of several lines on a retail website. Then, the cyber-storekeeper makes 
it to follow to the concerned producers. The latter separately carry out order-picking, giving their parcels to a solitary LSP to avoiding multiple deliveries (Monnet, 2008). Grouping parcels by customer (it's, in fact, a type of cross-docking operation), then takes place: the multi-suppliers' orders are thus strengthened. Once assembled, orders soon start to be delivered to Internet users. A single HD per household makes this alternative unmistakably the most economic and the most ecological variant.

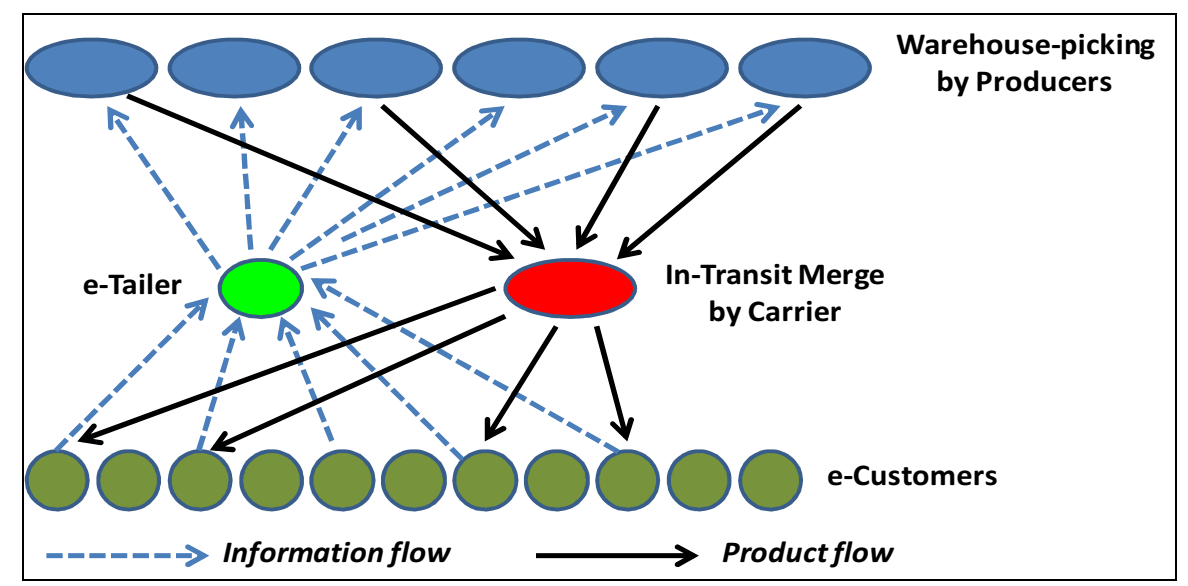

Figure 1: Upstream warehouse-picking and in-transit merge operations (adapted from Chopra \& Meindl, 2004)

Let us add that we regularly encounter this first alternative in the editorial e-supply chain, because of a plethoric offer of several million on-line articles. On the other hand, it is absent in the e-grocery sector. Indeed, the offer of cyber-markets is only composed of approximately five or six thousand very fast moving articles. Consequently, grocery items are rather stored downstream in warehouses (or depots), allocated to distributors. It corresponds to the two other order-picking alternatives. According to Yrjölä (2003), a logistics unit dedicated to e-grocery operations justifies itself since the number of on-line consumers per $\mathrm{km}^{2}$ is increased. Concerning final delivery, we also observe several variants: the management of HD being integrated in or delegated to LSPs, or hybrid.

\subsection{Store-picking}

On-line retailers, who choose to lean on a network of existing stores, opt for a very simple process and a quickly operational process. This model, which was the cornerstone of Tescos egrocery success, is based on the fact that on-line orders are transferred to the store nearest to the e-consumer's location. Order-picking is often made by employees of the store concerned (they pick articles from shelves) and, once the basket has been filled, HDs are, in general, 
made by the storekeeper or by a LSP, with a multi-temperature vehicle. So, using existing infrastructures, store-picking is characterized by a reduced investment and, therefore, by a very short ROI (Return On Investment). Another asset of this model is in the fact that on-line consumers can opt to pick-up goods purchased, directly in store (as shown in Figure 2), avoiding transportation costs in this way. So, this model also constitutes an OHD (Out of Home Delivery) alternative. However, this second model contains a risk: that of the disturbance of traditional in-store customers by pickers. Faced with this eventuality which could entail leaks of consumers, Ogawara et al. (2003) suggest adopting warehouse-picking as soon as the customer catchment area has good potential. In any case, the store-picking model constitutes the proof that on-line business does not mean the death of outlets: indeed, their mobilization could be an invaluable support to e-logistics.

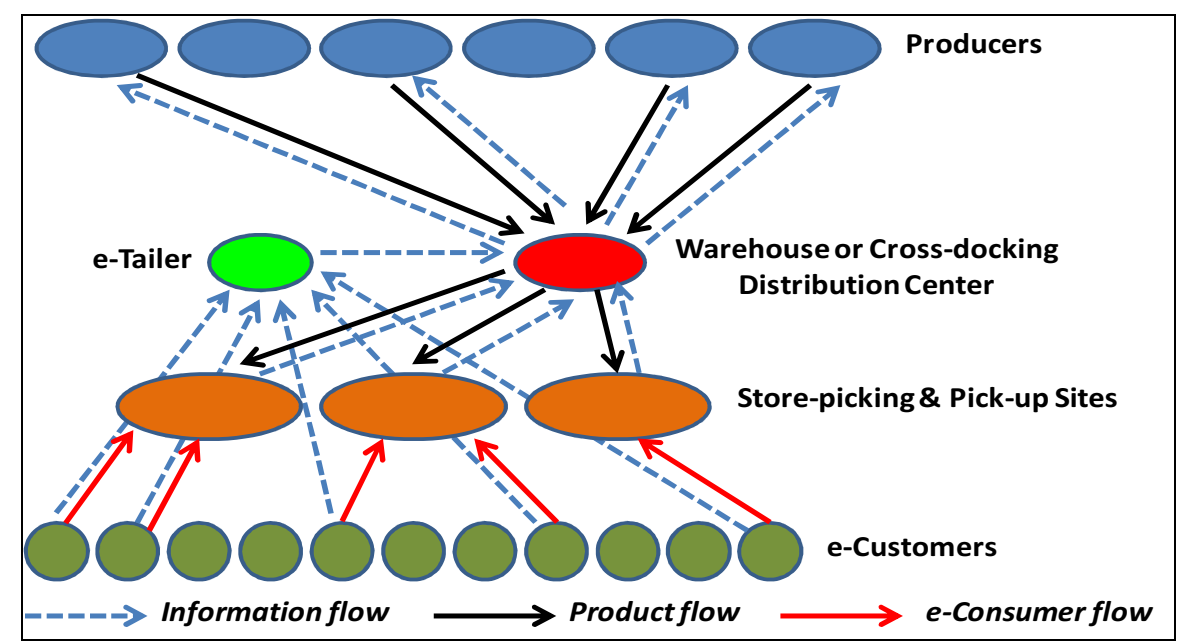

Figure 2: Downstream store-picking and e-consumers pick-up operations (adapted from Chopra \& Meindl, 2004)

These two basic models of B2C logistics continue to be the object of academic works (Marouseau, 2007), but are the facts? Do we find these two models in the practices of on-line storekeepers, in particular in the French market?

\subsection{Logistics practices observed by French cyber-traders}

To sketch a state of the art of the logistics practices by French cyber-storekeepers, we adopted a research methodology (cf. Frame 1) that we have however limited, for questions of opportunity, to three business sectors: floral, editorial and food. 
The mobilized approach is of qualitative nature. Fifteen semi-directive interviews, of an average duration of one hour and thirty minutes, were conducted: three in the floral sector (Interflora, Aquarelle and Bebloom), 2 in the editorial sector (Fnac and Alapage), 10 in the food sector with seven French large distributors (Carrefour, Auchan, Cora, Galeries Lafayette, Intermarché, Système U and Leclerc). These conversations were then the object of an accurate analysis of the speech, in the sense of Paillé \& Mucchielli (2003), what allowed in the end to put in perspectives 12 e-supply chains.

Frame 1: Methodology of research used

This research, from which the Table 1 is established, gives a summary, allowing us to note that the studied e-supply chains often lean on organizations stemming from the old economy and therefore already integrate preoccupations about urban logistics.

\begin{tabular}{|c|c|c|c|c|}
\hline $\begin{array}{c}\text { Type of } \\
\text { e-supply chain }\end{array}$ & Supply & Flow management & Logistics model & LSPs involvement \\
\hline \multirow{2}{*}{ Floral products } & \multirow{2}{*}{$\begin{array}{l}\text { Limited } \\
\text { Only some } \\
\text { SKU tens }\end{array}$} & \multirow{2}{*}{$\begin{array}{c}\text { Pull } \\
\text { Bunch built-to-order }\end{array}$} & $\begin{array}{l}\text { Store-picking for Interflora } \\
\text { (brick-and-mortar) }\end{array}$ & $\begin{array}{c}\text { None } \\
\text { (insourcing of deliveries) }\end{array}$ \\
\hline & & & $\begin{array}{c}\text { Warehouse-picking for } \\
\begin{array}{c}\text { Aquarelle \& Bebloom } \\
\text { (pure-players) }\end{array} \\
\end{array}$ & $\begin{array}{c}\text { Transport Outsourcing } \\
(\text { Chronopost...) }\end{array}$ \\
\hline Editorial products & $\begin{array}{c}\text { Very large } \\
\text { Several } \\
\text { millions SKUs }\end{array}$ & \begin{tabular}{|c|} 
Push \\
$\begin{array}{c}\text { Large stocks, upstream } \\
\text { by suppliers }\end{array}$
\end{tabular} & $\begin{array}{c}\text { Warehouse-picking } \\
\text { - insourced by Fnac } \\
\text { (brick-and-mortar) } \\
\text { - outsourced by Alapage } \\
\text { (pure-player) }\end{array}$ & \begin{tabular}{|} 
Transport Outsourcing \\
(Chronopost...) and \\
Storage Outsourcing \\
by Alapage
\end{tabular} \\
\hline \multirow[t]{2}{*}{ Food products } & \multirow{2}{*}{$\begin{array}{c}\text { Large } \\
\text { Several } \\
\text { thousand SKUs }\end{array}$} & \multirow{2}{*}{$\begin{array}{c}\text { Push } \\
\text { Large stocks, } \\
\text { downstream by retailers } \\
\text { (brick-and-mortar) }\end{array}$} & $\begin{array}{c}\text { Store-picking for } \\
\text { Intermarché, Système } U \& \\
\text { Leclerc }\end{array}$ & $\begin{array}{c}\text { None } \\
\text { Système U \& Leclerc } \\
\text { don't practise HD }\end{array}$ \\
\hline & & & $\begin{array}{c}\text { Warehouse-picking for } \\
\text { Carrefour, Auchan, Cora et } \\
\text { Télémarket }\end{array}$ & $\begin{array}{c}\text { Adaptable } \\
\text { Carrefour practices } \\
\text { outsourcing, whereas } \\
\text { Auchan insources }\end{array}$ \\
\hline
\end{tabular}

Table 1: Logistics practices observed by French cyber-storekeepers

(Durand, 2007)

If we had the opportunity to work on three business sectors, we only had time to look at egrocery in depth, for which we have conducted numerous interviews. It is for that reason that afterwards we are going to limit our paper to it, by focusing more exactly on the evaluation of three distribution systems that the French distributors Intermarché and Auchan have developed. Later, we will conduct additional interviews in floral and editorial sectors to do the same thing. 


\subsubsection{The Expressmarché logistics model}

Pick-up directly in store, an alternative to store-picking, seems to have convinced the most hesitant French distribution brands (Durand, 2009). It is in particular the case of Intermarché, whose will is to control its logistic costs (the main reason behind this choice). It is, therefore, on 300 supermarkets that Expressmarché, the cyber-market of the grouping, leans today. Intermarché has chosen to take advantage of the density of its network (a selling point every $18 \mathrm{~km}$ ). If $\mathrm{HD}$ can also be envisaged because of this very good territorial cover, Expressmarché was also made available on its two pick-up or OHD alternatives: the classic in store pick-up and the drive-through, which means that Internet users do not need to alight from their vehicles.

\subsubsection{The Auchandirect logistics model}

Auchan is one of the first large French retailers to have invested in the e-grocery market by launching Auchandirect in 2001. At this time, the customer catchment area, served by the central warehouse of Chilly-Mazarin (near Paris), was limited to the southern region of Paris. Since then, whilst sticking with warehouse-picking, Auchandirect has widened its national coverage by opening five new sites: a second in Ile-de-France and four near major cities (Lyon, Lille, Toulouse and Marseille). In 2004, Auchan branched its digital distribution out further, developing an alternative cyber-market in parallel called Chronodrive.

\subsubsection{The Chronodrive logistics model}

The Chronodrive alternative corresponds to an original OHD concept. Orders are prepared in nearby depots, situated in big city suburbs. To differentiate from warehouse-picking, we use the term "depot-picking" to describe the activity of these infrastructures, exclusively dedicated to storage and to order-picking (they are not stores). Internet users come to pick up and adjust their orders. If warehouse-picking can only be associated to HD and if the store-picking authorizes both HD and basket pick-up, Chronodrive only allows the order pick-up. Except for the fact that it favors the territorial extension of the of Auchan's e-grocery activities, the Chronodrive alternative allows the distributor to by-pass the HD problem. Currently about twenty sites are operational in France and model profitability seems satisfactory. The opening of new depots is programmed, the objective being, according to Silly (2008), to quickly reach one hundred. 
We have just sketched a state of the partial art of the logistical alternatives retained by French cyber-storekeepers and, more exactly, by French e-grocers stemming from the "brick-andmortar" system, that is to say from a system where it is possible backing to an existing network of stores. It is indeed necessary to know that the quasi-totality of French pure cyberstorekeepers, which dashed into e-grocery, failed in delivering goods to their customers because, effectively, they didn't have networks of stores. In summary, we have to underline that, faced with difficulties caused by HD, French e-grocers are more and more interested in two types of OHD: (1) pick-up directly from their stores; (2) pick-up from suburban depots as Auchan via its Chronodrive model.

Let us underline that, generally speaking, deliveries OHD are less expensive than HD, at least for e-grocers! Nothing proves however the ecological interest of OHD. Besides, the research of Browne et al. (2005) shows that OHDs could be provide a result contrary to the objective of reducing greenhouse gas (GHG) emissions. This system could indeed generate more movements than within the framework of traditional in-store shopping. Such uncertainties about the advantages of OHD with regard to HD require simulations to be undertaken from typical scenarios of urban logistics and, especially, that comparative analysis of the environmental disturbances produced by each of these scenarios is carried out. The next section will look at this, by studying three e-grocery logistics models.

\section{INTERACTIONS BETWEEN E-GROCERY AND CITY LOGISTICS}

As stated by Ségalou et al. (2004), urban goods movement (UGM) is composed of several categories and subcategories. In this paper, we are interested in two types of movements: last mile inter-establishment movements and end-consumer movements, which are susceptible to evolve with the development of e-grocery. Inter-establishment movements represent about 40$45 \%$ of the total UGM in an urban area (Patier, 2002). The last mile flows of retailing activities are estimated to be $11 \%$ of total UGM (Routhier et al., 2009), whereas those related to only grocery are about $9 \%$.

End consumer movements represent about 45\%-50\% of the total UGM (Patier, 2002). Nowadays, most of these flows are tradition shopping trips, but the new forms of distribution need to start to be taken into account from a global city logistics point of view. E-grocery 
currently represents less than $5 \%$ of total shopping trips and could represent, according to Georget et al. (2008), more than 15\% in 2020. Regarding transport models from a city logistics point of view, three main strategies are commonly seen in practice: (1) HDs from a specific warehouse; (2) HDs from a store; (3) OHDs through a store or a depot.

\subsection{Home Deliveries from a dedicated warehouse}

In the "HDs from a specific warehouse" case, orders are prepared by a warehouse-picking process. Important changes are then noted in the supply chain because this new and dedicated warehouse is not located in a peripheral area. The ordered products are delivered to the place of consumption using light goods vehicles, through an optimized route. These trips are made by delivery vehicles and can be assimilated to traditional e-commerce HD with more restrictive constraints (Durand \& Vlad, 2011).

\subsection{Home Deliveries from a traditional store}

In the "HDs from a supermarket" case, orders are this time prepared by a picker, in the lanes and in the shelves of a store. This outlet, generally a supermarket of a 2,000 square meter surface, is located on the outskirts of the urban area, a few miles away from the consumer home. Let us add that there are no major changes in the supply process of the store. The purchased products are either directly delivered at home or picked up by the consumer, mainly by car, avoiding queues and waiting times. These trips can be then assimilated to personal trips for shopping purposes (Gonzalez-Feliu et al., 2010).

\subsection{Out of Home Deliveries via a store or a depot}

In the third and last case, the "OHDs through proximity pick-up points" case, the main changes in the supply process consist above all of including new local depots. This time, indeed, the ordered products are directly prepared either in a depot (that is to say in a new site) through a depot-picking process, or in a store by a classical store-picking process. Let us add that these two different types of points, in which the products are finally picked up by the final consumer, are both located near the place of consumption (Augereau \& Dablanc, 2008).

Finally, we would like to put forward a small overview of e-grocery development. If on-line sales concern almost all business sectors, one has to admit that e-grocery still represents a niche market: its turnover was only about 1.2 billion euros in 2009 in France. Besides this, currently only about three million French Internet users use on-line supermarkets. This type of 
sale is attractive firstly for reasons of practicality and of time saving. Consumers want to save time during food purchasing in two ways: (1) on going to the store by reducing (or even by eliminating) their round trip time and, also, the time of spent looking for a parking space; (2) during their time in store by eliminating waiting times at food preparation counters and at the checkout. Internet users underline the practicality of on-line sales, also in two ways: (1) on-line stores are continuously open, 24 hours a day - therefore this scenario allows transactions at any time of the day; (2) on-line orders can be directly delivered or dropped off at pick-up points. Let us add that the consideration of environmental problems also seems to push households to develop their Internet purchases: the environmental impact seems rather positive because of the reduction of movements and of GHG.

The cost of this service however seems to constitute the major obstacle to e-grocery development because, in the mind of many French people, on-line shopping is more expensive: either the price of products sold on Internet is higher because it integrates the cost of basket picking and delivery costs; either the price of articles is situated at the same level as that practiced in store and it is advisable to add to this the logistic service costs. Less sensitive to this cost than the other SPCs (Socio-Professional Categories), the SPC+ (upper SCP) is also, at the moment, the category the most attracted by e-grocery: more half of their food expenses would already be made in cyber-markets, while the offer, a real element of differentiation between e-grocers, is particularly reduced with only 7,000 references on average, compared to 40,000 for a traditional supermarket.

\section{SIMULATION AS AN EVALUATION TOOL FOR E-LOGISTICS}

In this section, we provide an assessment of three distribution scenarios adopted by French egrocers: (1) one that allows only warehouse-picking, which is translated into HD services only; (2) one based on store-picking and that combines HD services with in-store pick-up shopping trips; (3) the last that, conversely, only offers a pick-up service from a nearby depot.

\subsection{The proposed scenarios}

In order to isolate the effects of e-commerce from other effects, such as population growth or changes in retailing demography, we propose several hypothesis built from the reference 
presented above by changing only the end-consumer supply organizational schemas (with the respective inter-establishment changes if applicable). The proposals are:

- S0: A reference situation, corresponding to those of the urban area of Lyon in 20052006 (Gonzalez-Feliu et al., 2010).

- S1: A "warehouse-picking \& HD" scenario. This hypothesis supposes that the only distribution channel for e-grocery services is that of HDs using a warehouse-picking strategy. This supposes the use of a regional depot, then the simulation of HD routes from this depot. This scenario supposes that only large e-grocery groups are proposing these services.

- S2: A "store-picking \& HD" scenario based on the assumption that all households asking for e-commerce services are served by a store within their urban area. This scenario supposes two types of retailing activities: small retailers will cover small routes from all locations within the urban area, whereas big stores will use peripheral stores as the starting point of longer routes.

- S3: A "depot-picking \& OHD" scenario based on the assumption that only depotpicking can be used by the inhabitants for e-commerce purposes. These depots are located in the areas having already a supermarket, in order to obtain a realistic set of depots.

For each hypothesis, a quota of 10 to $50 \%$ of e-commerce users is supposed. Moreover, both warehouse-picking and store-picking strategies will be simulated each time.

\subsection{Simulation procedure}

The simulation procedure chart is shown in Figure 3. We assume that all strategies follow a store-picking inventory schema, since this is nowadays the most interesting in terms of environmental and social impact (Durand, 2010). For this reason, only B2C flows will be simulated. 


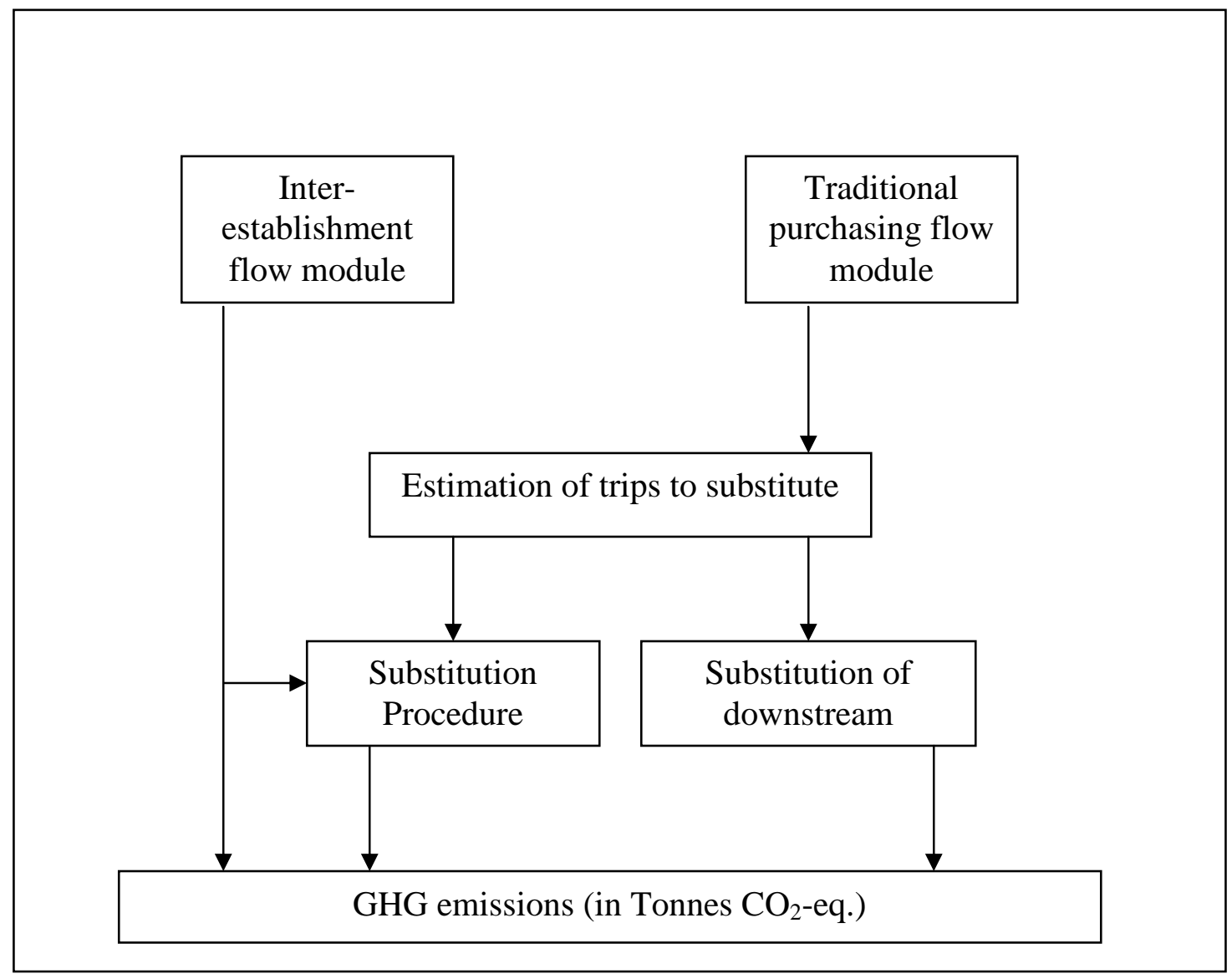

Figure 3: Integrated simulation procedure chart

(adapted from Gonzalez-Feliu et al., 2012)

The simulation procedure is an adaptation of Gonzalez-Feliu et al.'s method (2012), defined as follows. First, following each scenario's assumptions and hypotheses, the input data files are generated. Note that the simulation needs, as input, an e-commerce user rate defined as the percentage of the total number of households using e-commerce. From these different rates, we estimate the number of shopping trips to be substituted, using the substitution procedures defined by Gonzalez-Feliu et al. (2012). Then, we use a catchment area model (Gonzalez-Feliu et al., 2010) to identify each pair of origin-destination, i.e. to find, for a potential delivery, its origin (a store, a warehouse or a depot) and its destination (a household). Following Alligier's (2007) and Durand \& Vlad's (2011) considerations, we define two types of HD routes, one for store-picking deliveries and one for warehouse-picking last mile trips. Then, we estimate the routes using a procedure adapted from Gendron \& Semet (2009) and Routhier et al. (2009). This procedure works as follows: given a starting point and a set of possible destinations of a route, we assign a number of destinations to the route in order to minimize the total transport 
cost, respecting two main constraints: (1) the total number of driving hours including the driver's breaks is lower than 9 (legal value); (2) the vehicle capacity is not reached. The time constraints related to the customer's preferences are taken into account following an empirical method (Gonzalez-Feliu, 2008).

The B2B flows delivering the different retailing activities of a city are extracted from a general diagnosis of the considered city's flows, using the Freturb model (Routhier \& Toilier, 2007). In order to evaluate the real impact of $\mathrm{B} 2 \mathrm{C}$ flows on urban freight transport, we take into account all the urban B2B flows, where last mile retailing activities represent less than $10 \%$ in terms of road occupancy rates. These flows are given by Freturb's generation module using, as inputs, an establishment file and a geographic division of the simulation area. Then we substitute the flows corresponding to the new B2C activities (i.e. warehouse-picking HDs and depot-picking HDs, whose impact on B2B flows is positive [decrease of the number of last mile deliveries]).

Finally, the results are aggregated to estimate the total travelled distances by type of vehicle. Three indicators are proposed. First is the overall distance, in $\mathrm{km}$, for each category of flows. Second are the road occupancy rates, in $\mathrm{PCU}^{1}$. Third are GHG emissions rates, in tons of equivalent $\mathrm{CO}_{2}$, estimated using the IMPACT ADEME software (ADEME, 2003). The area of application is the urban community of Lyon, the second largest urban area in France in terms of population, Paris Metropolitan Region being the first. This choice has been made mainly because of data availability (all the required data files are complete and have been previously processed for modeling and simulation tests). Lyon urban area consists of about 2,000,000 inhabitants and 800,000 households. We use a database that derives from the 2006 household trip survey of Lyon urban area (Grand Lyon, 2011), and the 2005 establishment censorial database (SIRENE $\left.{ }^{2}\right)$.

\subsection{Simulation results}

We are thus able to establish a number of results, which we could develop a comparative analysis of three systems studied. These results are expressed in $\mathrm{Km}$ (see Table 2), that are directly linked to the transportation costs generated by the endorsement of the e-grocery and in a second time to calculate the road occupancy rates (in km.PCU), then the GHG emissions (in

\footnotetext{
${ }^{1}$ Road occupancy rates are estimated in Private Car Units (PCU), defined as follows: 1 private car = 1 PCU; 1 light goods vehicle $=1.5 \mathrm{PCU}, 1$ simple truck $=2 \mathrm{PCU}$ and 1 semi-articulated $=2.5 \mathrm{PCU}$.

${ }^{2}$ The SIRENE files are produced by the French Institute of Statistics (INSEE).
} 
tons of $\mathrm{CO}_{2}$ equivalent units). Note that the reference scenario produces nearly 2,300 billion kilometers per year in Lyon's urban. Moreover, the downstream delivery flows in 2006 were considered negligible.

\begin{tabular}{|c|c|c|c|c|c|}
\hline & IEM & PDM & ST & Total \\
\hline \multicolumn{2}{|c|}{ Reference } & 625 & 0 & 1350 & 1975 \\
\hline \multirow{5}{*}{1} & $10 \%$ & $-0,24 \%$ & $6,13 \%$ & $-0,10 \%$ & $4,05 \%$ \\
\hline & $20 \%$ & $-0,57 \%$ & $12,20 \%$ & $-1,00 \%$ & $7,48 \%$ \\
\hline & $30 \%$ & $-1,23 \%$ & $18,33 \%$ & $-2,10 \%$ & $10,71 \%$ \\
\hline & $40 \%$ & $-1,80 \%$ & $24,47 \%$ & $-3,20 \%$ & $13,97 \%$ \\
\hline & $50 \%$ & $-2,36 \%$ & $30,53 \%$ & $-4,30 \%$ & $17,18 \%$ \\
\hline \multirow{5}{*}{2} & $10 \%$ & $0,00 \%$ & $1,33 \%$ & $-0,40 \%$ & $0,64 \%$ \\
\hline & $20 \%$ & $0,00 \%$ & $2,73 \%$ & $-1,30 \%$ & $0,98 \%$ \\
\hline & $30 \%$ & $0,00 \%$ & $4,07 \%$ & $-2,20 \%$ & $1,28 \%$ \\
\hline & $40 \%$ & $0,00 \%$ & $5,47 \%$ & $-3,20 \%$ & $1,55 \%$ \\
\hline & $50 \%$ & $0,00 \%$ & $6,80 \%$ & $-4,10 \%$ & $1,85 \%$ \\
\hline \multirow{5}{*}{3} & $10 \%$ & $-0,19 \%$ & $0,40 \%$ & $-1,30 \%$ & $-0,68 \%$ \\
\hline & $20 \%$ & $-0,43 \%$ & $0,75 \%$ & $-3,20 \%$ & $-1,81 \%$ \\
\hline & $30 \%$ & $-0,61 \%$ & $1,15 \%$ & $-5,00 \%$ & $-2,83 \%$ \\
\hline & $40 \%$ & $-0,80 \%$ & $1,55 \%$ & $-6,90 \%$ & $-3,91 \%$ \\
\hline & $50 \%$ & $-1,04 \%$ & $1,95 \%$ & $-8,80 \%$ & $-5,01 \%$ \\
\hline
\end{tabular}

Table 2: Simulation Results in total traveled distances $(\mathrm{km} /$ year $)$

(IEM: Inter-Establishment Movements - PD: Proximity Delivery Movements - ST: Shopping Trips)

From them, we can observe that scenarios 1 and 2 lead to an overall distance increase. In all cases, pick-up and delivery flows, whose costs are assumed by retailers proposing proximity delivery services, are not negligible. Thus, we can state that these costs have to be taken into account, not only in the optimization process but also in pricing and tariff developments, because they have an incidence on the company benefit margins. More precisely, the usage of peripheral warehouses with only HD for e-grocery leads to large HD distances (each route is about 150-250 km, according to Durand \& Vlad [2011], and delivers 35-50 households). This scenario (1) is the less favorable in terms of travelled distances. Scenario 2, which mixes HD and pick-up services, follows the same trend, but with much lower impacts. In both cases, the travelled distances of HD are bigger than the gains observed on both last mile B2B flows and shopping trips. This can be explained by the fact that people individually optimize their shopping trips, sometimes by making work-shopping-household trips, which lead to a distance 
increase of 2-5 km per trip (Gonzalez-Feliu et al., 2011), much lower than the associated distances of a delivery route. Scenario 3, which uses nearby depots, presents a decreasing trend of distances. This is due to the fact that depot delivery routes are better optimized than HD routes. This scenario is then the most favorable, but the gains are contained: about $5 \%$ of overall distance reduction, mainly due to supermarket and hypermarket shopping trip decreasing.

\begin{tabular}{|c|c|c|c|c|c|c|}
\hline & \multicolumn{4}{|c|}{ Road occupancy rates } & \multirow{2}{*}{$\begin{array}{c}\text { Tons } \\
\text { CO2-eq }\end{array}$} \\
\hline & & IEM & PDM & $\mathrm{ST}$ & Total & \\
\hline \multicolumn{2}{|c|}{ Reference } & 1320 & 0 & 1350 & 2670 & 320000 \\
\hline \multirow{5}{*}{1} & $10 \%$ & $-0.50 \%$ & $9.20 \%$ & $-8.90 \%$ & $-0.10 \%$ & $-0.10 \%$ \\
\hline & $20 \%$ & $-1.20 \%$ & $18.30 \%$ & $-19.00 \%$ & $-1.00 \%$ & $-1.20 \%$ \\
\hline & $30 \%$ & $-2.60 \%$ & $27.51 \%$ & $-29.10 \%$ & $-2.10 \%$ & $-2.40 \%$ \\
\hline & $40 \%$ & $-3.80 \%$ & $36.69 \%$ & $-39.30 \%$ & $-3.20 \%$ & $-3.30 \%$ \\
\hline & $50 \%$ & $-5.00 \%$ & $45.80 \%$ & $-49.40 \%$ & $-4.30 \%$ & $-4.60 \%$ \\
\hline \multirow{5}{*}{2} & $10 \%$ & $0.00 \%$ & $2.00 \%$ & $-2.80 \%$ & $-0.40 \%$ & $-0.40 \%$ \\
\hline & $20 \%$ & $0.00 \%$ & $4.11 \%$ & $-6.90 \%$ & $-1.30 \%$ & $-1.30 \%$ \\
\hline & $30 \%$ & $0.00 \%$ & $6.10 \%$ & $-10.90 \%$ & $-2.20 \%$ & $-2.20 \%$ \\
\hline & $40 \%$ & $0.00 \%$ & $8.19 \%$ & $-15.00 \%$ & $-3.20 \%$ & $-3.20 \%$ \\
\hline & $50 \%$ & $0.00 \%$ & $10.20 \%$ & $-19.00 \%$ & $-4.10 \%$ & $-4.10 \%$ \\
\hline \multirow{5}{*}{3} & $10 \%$ & $-0.39 \%$ & $0.80 \%$ & $-3.10 \%$ & $-1.30 \%$ & $-1.40 \%$ \\
\hline & $20 \%$ & $-0.90 \%$ & $1.50 \%$ & $-7.40 \%$ & $-3.20 \%$ & $-3.20 \%$ \\
\hline & $30 \%$ & $-1.31 \%$ & $2.30 \%$ & $-11.70 \%$ & $-5.00 \%$ & $-5.10 \%$ \\
\hline & $40 \%$ & $-1.70 \%$ & $3.10 \%$ & $-16.00 \%$ & $-6.90 \%$ & $-7.00 \%$ \\
\hline & $50 \%$ & $-2.18 \%$ & $3.90 \%$ & $-20.30 \%$ & $-8.80 \%$ & $-9.00 \%$ \\
\hline
\end{tabular}

Table 3: Simulation Results in road occupancy rates (km.PCU / year)

And in T. $\mathrm{CO}_{2}$-eq. / year in the Lyon urban area

(IEM: Inter-Establishment Movements - PD: Proximity Delivery Movements - ST: Shopping Trips)

Regarding road occupancy rates, we can observe that scenario 1, which uses specific peripheral warehouses with only HD for e-grocery, and scenario 2, which mixes HD and pick-up services, are less favorable in terms of road occupancy rates than scenario 3, which uses nearby depots. In the two first scenarios, the decrease in individual movements related to purchasing do not efficiently compensate the increase due to the use of commercial vehicles for HD services, which does not seem to be optimized. In scenario 1, almost all the gains made in terms of shopping trips are neutralized by long and sub-optimized HD routes. In scenario 2, these routes are better optimized (the starting point is in general inside the urban zone or in the first 
periphery) but, in general, car pick-up generates more distance and, thus, more Road occupancy rates than traditional shopping. Scenario 3, the "pick-up everything" is more favorable, but the gains in Road occupancy rates remain small: less than $9 \%$ gain in $\mathrm{T}$. $\mathrm{CO}_{2}$-eq. when the utilization rate is $50 \%$.

If we convert these results into GHG emissions rates, we observe than the variations are similar (the differences between road occupancy rates and GHG emissions present differences of about 0.2-0.4\%). Note that GHG emissions rates have been estimated assuming the current fleet distribution, i.e. almost the totality of vehicles are diesel, and the ages of these vehicles are distributed using ADEME's (2006) ratios. For these reasons, road occupancy and GHG emissions rates are almost matching. Making further assumptions, as for example transferring freight from high polluting schemes (because vehicles used are more polluting) to $\mathrm{B} 2 \mathrm{C}$ schemes, using methane or electric vehicles, will increase these gains (in terms of GHG emissions) without altering the others (travelled distances and road occupancy rates). This highlights an interesting question: what category of actions has to be considered as the basis for $\mathrm{CO}_{2}$ reduction? Technology do not seems to change the organization of a supply chain, and only organizational changes seem to be fundamental for an efficient GHG reduction (Routhier et al., 2009). Indeed, only organizational changes (as shown in our scenario simulation) have an impact on congestion. However, it is important to support the choices of both public authorities and private actors (Gonzalez-Feliu and Morana, 2010) to help them into finding a convergence between individual cost reduction targets and a collective vision of congestion reduction and environmental-friendly practices.

\section{CONCLUSION}

In this paper, we have given an overview on the latest developments in e-grocery distribution and presented a scenario analysis using an empirical simulation approach. Three scenarios, each of them related to a new form of $\mathrm{B} 2 \mathrm{C}$ services (HDs, shopping trip in a car and proximity pick-up points) have been presented and simulated. We can observe that scenario 1, the "allHD", and scenario 2, which mixes HD and pick-up services, appear to be less favorable than scenario 3. While the individual purchase movements decrease, the use of commercial vehicles for at HD does not seem to be optimized in this configuration. The resulting gain in GHG emissions is respectively about $4.3 \%$ and $4.1 \%$ when the utilization rate is $50 \%$. Scenario 3 , the "pick-up everything" would apparently be more favorable: almost a 9\% GHG emission 
reduction when the utilization rate is $50 \%$. This reflects a sharp decline in motorized shopping trips, the assumption was made that the depots are located near the heart of residential neighborhoods and the density of these points is sufficient to lead to changes in user behavior, including the use of their car. Finally, through the external impacts of household supplies, we show that consolidation of HDs and proximity reception points (where most trips are made on foot) can lead to significant savings.

The remaining question concerns the managerial implications of the three scenarios. Regarding the first, in which $40 \%$ of e-shoppers opt for an in store pick-up service, it raises the key question of the nature of the operator who must support the HD services. Does the e-tailer assume this role? Is not that rather the role of an LSP to do it? This second alternative would be to fine-tune the prospect of consolidating and sharing online order processing on urban platforms to reduce the number of HDs per household.

Regarding scenario 2, the "all HD", the internalization of HD appears relevant because it generates transport cost savings. However, LSPs specialized in the field, starting with Star's Service for example in France, also seem able to offer quality services at a very reasonable price. Finally, the local depot option is the most interesting in terms of reducing $\mathrm{CO}_{2}$ emissions, but also the most costly and longest in implementation. The deployment of local depots requires significant investment (Augereau \& Dablanc, 2008), which inevitably leads to higher management costs. A pooling of these infrastructures through urban platforms could then be the best solution to the urban delivery problem (Paché, 2010), although this strategy remains long and arduous (Gonzalez-Feliu \& Morana, 2010). 


\section{REFERENCES}

Alligier, L., (2007), Mesurer l'impact du commerce électronique sur la logistique urbaine, Thèse de doctorat en Sciences Economiques, Université Lumière (Lyon 2), octobre.

Augereau, V., \& Dablanc, L., (2008), An Evaluation of Recent Pick-up Point Experiments in European Cities: the Rise of two Competing Models? in Innovations in City Logistics, ed. Taniguchi, E., \& Thomson, R.G., Nova Science, p 301-320.

ADEME (2003), Logiciel IMPACT-ADEME version 2.0.: Émissions de polluants et consommation liées à la circulation routière, Livret de présentation, Coll. Connaître pour agir, ADEME Editions.

Baglin, G., Bruel, O., Garreau, A., Greif, M., Kerbache, L., et van Delft, C., (2005), Management industriel et logistique : conception et pilotage de la supply chain $\left(4^{\text {ème }}\right.$ édition), Economica.

Browne, M., Castro, J., Nemoto, T., et Visser, J., (2005), Intermodal transport and city logistics policies, $4^{\text {th }}$ International Conference on City Logistics, Langkawi (Malaysia).

Chopra, S., \& Meindl, P., (2004), Supply Chain Management: Strategy, Planning and Operations, Pearson Prentice Hall, New-Jersey.

De Koster, M.B.M., (2002), Distribution Structures for Food Home Shopping, International Journal of Physical Distribution \& Logistics Management, vol 32, n5, p 362-380.

Dornier, Ph-P., \& Fender, M., (2001), La logistique globale : enjeux, principes, exemples, Editions d'Organisation, Paris.

Durand, B., \& Vlad, M., (2011), Auchan et Intermarché : deux styles de glisse sur la vague de la cyber-épicerie, in Revue des cas en gestion, ed. Joffre, O., \& Simon, E., Editions EMS Management \& Société (www.revuecasgestion.com), n5, p 39-48.

Durand, B., (2010), e-commerce et logistique urbaine : quand le développement durable s'en mêle..., Revue Française de Gestion Industrielle, vol 29, n 2, p 7-26.

Durand, B., (2009), Mutations logistiques de la cyber-épicerie française: quand les groupements d'associés défient la distribution intégrée, Logistique \& Management, vol $17, \mathrm{n}^{\circ} 2, \mathrm{p}$ 51-64.

Durand, B., (2008), «Quoi de neuf en France dans le B to C ? La logistique suit-elle enfin ? », $11^{\text {ème }}$ Colloque Etienne THIL, Université de La Rochelle.

Durand, B., (2007), La dimension stratégique des chaînes logistiques du BtoC, in La gestion des chaînes logistiques multi-acteurs : perspectives stratégiques, ed. J. Spalanzani \& G.Paché, Grenoble, Presses Universitaires de Grenoble, Chapitre 10, p 185-202.

Gendron, B., \& Semet, F., (2009), Formulations and Relaxations for a Multi-Echelon Capacitated Location-Distribution Problem, Computers and Operations Research, vol 36, p 1335-1355.

Georget, P., Damery, N., et Gallois, J.B., (2008), Quel avenir pour le commerce en France ? Neuf patrons vous en disent plus, Somogy Société, Paris.

Gonzalez-Feliu, J., Ambrosini, C., et Routhier, J.L., (2012), New trends on urban goods movement modelling: proximity delivery versus shopping trips, European Transport, vol 50, paper $n^{\circ} 6,23 \mathrm{p}$.

Gonzalez-Feliu, J., Ambrosini, C., et Routhier, J.L., (2011), Comprendre les chaînes de déplacements pour l'approvisionnement des ménages : une approche empirique, $1^{\mathrm{er}}$ Colloque Frelon, Paris, Mars.

Gonzalez-Feliu, J., \& Morana, J., (2010), Are city logistics solutions sustainable? The Cityporto case, TeMA. Journal of Land Use, Mobility and Environment, vol. 3, n², p $55-64$

Gonzalez-Feliu, J., (2008), Planning and cost optimization for urban freight distribution: vehicle routing for multiple echelon distribution systems, LET Seminar, Lyon, June. 
Grand Lyon (2011), Programme Local de l'Habitat. Diagnostic, Agence d'urbanisme pour le développement de l'agglomération lyonnaise, Lyon, 193 p.

Marouseau, G., (2007), «Les revirements stratégiques de la grande distribution française en matière de commerce électronique $», 6^{\text {th }}$ International Congress Marketing Trends, Paris, Janvier.

Monnet, M., (2008), The Intermediary Conditions of Logistics Service Providers in the Context of Sustainable Development, Supply Chain Forum: an International Journal, vol 9, $\mathrm{n}^{\circ} 2, \mathrm{p} 78-87$.

Ogawara, S., Chen, J.C.H., et Zhang, Q., (2003), Internet Grocery Business in Japan: Current Business Models and Future Trends, Industrial Management \& Data Systems, vol 103, $\mathrm{n}^{\circ} 9, \mathrm{p} 727-735$.

Paché, G., (2010), Logistique urbaine mutualisée : quelle stratégie de différentiation pour le commerce alimentaire en ligne ?, Revue Française de Gestion Industrielle, vol 29, $\mathrm{n}^{\circ} 2$, p 27-48.

Paché, G., (2008), Efficient Urban e-Logistics: Mutualization of Resources and Source of Competitive Advantage, 7th International Meeting for Research in Logistics, Avignon, September.

Paillé, P., \& Mucchielli, A., (2003), L'analyse qualitative en sciences sociales et humaines, Armand Colin, Paris.

Patier, D., (2002), La logistique dans la ville, Celse, Paris.

Rohm, A.J., \& Swaminathan, V., (2004), A Typology of Online Shoppers Based on Shopping Motivations, Journal of Business Research, vol 57, $\mathrm{n}^{\circ}$ 7, p 748-758.

Routhier, J.L., Traisnel, J.P., Gonzalez-Feliu, J., Henriot, F., et Raux, C., (2009), ETHEL II: Energie, Transport, Habitat, Environnement et Localisations, Rapport final, Convention ADEME.

Routhier, J.L., \& Toilier, F., (2007), FRETURB V3, a Policy Oriented Software of Modelling Urban Goods Movement. In Proceedings of the 11th World Conference on Transport Research - WCTR'07, Berkeley (USA), June.

Ségalou, E., Ambrosini, C., et Routhier, J. L., (2004), The environmental assessment of urban goods movement, In Taniguchi, E., and Thomson, R.G., eds., Logistics Systems for Sustainable Cities, Elsevier, Amsterdam, 2004, p. 207-220.

Silly, G., (2008), Auchan réinvente l'e-commerce, Management, octobre, p 26-27.

Taniguchi, E., \& Kakimoto, T., (2003), Effects of e-commerce on urban distribution and the environment, Journal of Eastern Asia Society for Transportation Studies, vol 5, p 23552366.

Yrjölä, H., (2003), Supply Chain Considerations for Electronic Grocery Shopping, Dissertation for the degree of Doctor of Science in Technology, University of Technology, Helsinki, Finland. 